\title{
Transparency and National Treatment under the Chinese Flag
}

A lawyer's view of a decade of WTO membership and legal reforms

\section{Hubert Bazin}

\section{(2) OpenEdition \\ Journals}

Electronic version

URL: http://journals.openedition.org/chinaperspectives/5787

DOI: $10.4000 /$ chinaperspectives. 5787

ISSN: 1996-4617

\section{Publisher}

Centre d'étude français sur la Chine contemporaine

Printed version

Date of publication: 30 March 2012

Number of pages: 15-22

ISSN: 2070-3449

\section{Electronic reference}

Hubert Bazin, "Transparency and National Treatment under the Chinese Flag », China Perspectives [Online], 2012/1 | 2012, Online since 30 March 2015, connection on 28 October 2019. URL : http:// journals.openedition.org/chinaperspectives/5787; DOI : 10.4000/chinaperspectives.5787

(c) All rights reserved 


\title{
Transparency and National
}

\section{Treatment under the Chinese Flag}

\author{
A lawyer's view of a decade of WTO membership and legal reforms
}

\author{
HUBERT BAZIN*
}

\begin{abstract}
Since 2001, China has, overall, respected the commitments it made when it joined the WTO. However, no "WT0 spirit" has been observed that might have led it to go beyond the letter of these commitments, and very many non-tariff barriers are still in place. In view of the modernisation of its legal framework, is there room for improvements that would enable foreign companies to find their place more easily in a rapidly expanding market, or do structural obstacles stand in the way of the developments hoped for by its main partners?
\end{abstract}

KEYWORDS: China, WTO, market access, foreign investment, non-tariff barriers, rule of law

T en years after it joined the World Trade Organisation (WTO), China has still not become the country dreamed of by the Western governments with whom long negotiations on the conditions of its membership were conducted and who communicated to the public their enthusiasm for the prospects offered by the Chinese market. (1) Indeed, 2001 was a time of optimism, and in the spirit of the creation of the WTO at the 1994 Marrakech Conference, China seemed to be the missing link in what was envisaged as a cutting-edge organisation in terms of development towards increased international regulation. Today, China's economic development is as worrying as it is fascinating. Its political system has not followed the developments that certain observers anticipated in terms of greater integration into the international system, the opening-up of its market remains partial, and above all, the virtues of free trade shine less brightly in people's minds, as the failure of the Doha cycle testifies. Change and the permanence of the system intersect, rendering an analysis and assessment of China's membership all the more difficult.

This article sets out to retrace some of the developments that have taken place in China since it joined the WTO from the point of view of the modernisation of its legal framework and business practices. Necessarily subjective, the analysis aims to identify both the progress made and the resistance encountered. (2) At the end of this ten-year period, legal insecurity remains, in fact, one of the main problems raised in various surveys carried out on the mood of foreign companies present in China. ${ }^{(3)}$ The transparency requirements at the heart of WTO regulations are often demolished by the discretionary practices of the Chinese government, whilst the opacity shrouding certain markets, when added to persistent corruption, often gives foreign companies the feeling that they cannot operate within a framework of fair competition. The principle of national treatment has led to the revision of numerous legal provisions and to an almost total harmonisation of the system applicable to companies operating in China, but here again, its application has met with many failures since the discriminatory implementation of regulations for foreign and foreign-invested companies, to the extent of excluding the latter from the public markets of the future. The principle of judicial review exists in theory, but few and far between are the foreign companies that would risk going to court over an illegal government decision prejudicial to them.

Nonetheless, the Chinese market remains at the heart of the priorities of most multinational companies, who see it as a means of growth compared to markets that are mature, stagnant, or depressed. The balance sheet of some of them is beginning to show a significant weight of business carried out in China. An ambivalence continues to exist between the promises of a vast market that have been vaunted since the beginning of the reform and opening policy, and the problems of finding a place or developing in it. The legal framework has undeniably been modernised thanks to China's membership of the WTO, a guarantee of the disappearance of certain practices in an economy that was previously entirely planned. Yet it is difficult to discern a "WTO spirit" that might lead China to open up its market over and above the commitments it made and to abstain from playing on the letter of these commitments in order to favour Chinese companies at the expense of foreign businesses. Apart from the rules and principles of the WTO, the

Hubert Bazin, Attorney at Law (Paris Bar), Partner at DS Avocats (Beijing), has been advising European companies on their projects in China for 20 years. He is coordinator of the Ricci Dictionary of Chinese Law (to be published)

1. See the special issue of China Perspectives published to mark China's membership of the WTO, which traces the stages of this long negotiation and Western expectations in terms of, if not the rule of law, at least of legal stability and the opening up of trade. Chine-WTO, China Perspectives, no. 40, March-April 2002, and no. 41, May-June 2002; see www.cefc.com.hk/perspectives. php?iid=137 and www.cefc.com.hk/perspectives.php?iid=138 (consulted on 2 March 2012).

2. This analysis is based on almost 20 years' practice of business law, since 1993, in Paris, Shanghai, and Beijing, assisting European companies wishing to invest in China. The ideas developed in this article are those of the author and do not represent the structures in which he has practiced or is currently practicing.

3. In the annual survey carried out by the European Chamber of Commerce in China, 88 percent of the companies questioned consider the rule of law and transparency concerning the formulation and application of policies to be "important or very important," whilst 46 percent feel that Chinese government policies have become less equitable for foreign investment companies over the last two years: see the European Chamber of Commerce, European Business in China Business Confidence Survey 2011, http://cbi.typepad.com/china_direct/2011/05/2011european-business-confidence-survey-china-headlines.html. See also the annual White Paper of the American Chamber of Commerce in China, in particular the 2011 edition: www.amchamchina.org/whitepaper2011. 
question remains of whether the obstacles with which foreign companies are confronted are simply the result of the immaturity of a rapidly growing market, or of far more deeply-rooted structural obstacles and the impossibility of the current regime implementing the rule of law that it nevertheless continues to preach.

\section{A new modernisation phase thanks to WTO membership}

Hopes linked to China's membership of the WTO were running high ten years ago, proportionate with the years of negotiation - almost 15 - that had preceded it. The Chinese displayed an obvious desire to become integrated in world affairs, thereby avoiding the annual humiliation of the renewal process of the most favoured nation clause by the United States and protecting themselves, through the purchase of a multilateral insurance policy, against unilateral retaliation in necessarily conflictual trade relations. Over and above this, the strategy in certain governmental circles was to use this membership to make the reform and opening up policy irreversible, in order to force state-owned enterprises to reform and other government sectors to adapt their policies under a certain form of "external constraint."

Foreign expectations were also very high, with the prospect of a fall in customs duties and a far more extensive opening up of the market. Certain parties counted on the WTO to overcome the "internal barriers" that split the Chinese market into numerous provincial and local markets. (4) Moreover, in most people's minds, accession to the WTO was synonymous with a reinforcement of the rule of law that would lead to greater legal security and a gradual bringing into line of practices current on the Chinese market, notably with regard to intellectual property.

There exist several ways of interpreting the reasons that led developed countries to accept China's entry into the WTO at the beginning of the century. One of these interpretations is that although Western governments had realised the extent of industrial capacity transfers to China and of the trade balances, permanently in deficit, that would have to be taken on board, they thought they would find a form of compensation in the Chinese market since it would provide new outlets for their companies - in short, exchanging the deindustrialisation taking place in Europe and the United States for investments in an increasingly dynamic Chinese market, and accepting Schumpeterian "creative destruction" in favour of business activities with greater added value that could maintain the position of Western companies within a context of globalisation. It was a wager that could be justified by comparing the situation in China to that of other countries. Unlike India, China has favoured the widespread implantation of foreign groups on its soil since the beginning of the reform and opening policy, judging correctly that such investments are the best guarantee of massive technology transfers. Moreover, there are not so many countries in the world that possess both real domestic market potential and an industrial base for export. Have the promises of the wager been kept?

\section{The question of trading rights}

One of the main obstacles for foreign companies before China joined the WTO was the question of import and trading rights. Importing foreign products had to be done by specialist intermediaries holding an import-export licence, and they alone were authorised to deal in foreign currencies, whilst foreign-invested companies could only import the equipment and compo- nents needed to make their products, and could only export or sell on the local market products they had made themselves. The system was completed by the ban on setting up foreign-invested commercial companies. As a result, the system forced companies to invest in industrial capacity in order to sell their own products on the Chinese market and prevented them from developing and managing distribution networks for products manufactured abroad.

The dismantling of this system, incompatible with the rules of the WTO, was officially set down during the negotiations. We can only admire the way in which China has handled the transition. From the beginning of the 1990s, import-export rights were granted to an increasing number of Chinese companies. ${ }^{(5)}$ The initial monopoly of several big national import-export corporations ${ }^{(6)}$ has been relaxed, to the point where at the end of the decade, end-users forced many local import agents to go into competition while working for steadily diminishing commissions. From 1998-1999, a system developed on the sidelines of national regulations in the free trade zone of Waigaogiao in Shanghai, with the tacit support of the authorities. It allowed foreign companies to set up trading companies in this zone (usually simply a business address), to import their products there, and to invoice these in local currency to clients outside the zone. At the same time, "pilot" regulations were brought in to allow minority foreign investment in a few department stores, and distribution chains such as Carrefour could, with the support of local authorities, take the risk of defying the national authorities and begin to develop hypermarkets.

On 11 December 2001, the date on which China was to begin implementing its commitments, people were therefore prepared for the disappearance of the trading rights system inherited from the planned economy. The negotiations preceding entry into the WTO were particularly precise on matters of distribution, since China's commitments covered not only import and trading rights, accessible to all companies whether purely Chinese or foreignowned (except for a few designated products such as books), but also most services linked to distribution. At the end of 2004, foreign companies were authorised to set up companies funded entirely by foreign capital whose sole object was the marketing of products manufactured in China or abroad. (7)

The current freedom of distribution system is now so widespread that the harsh restrictions foreign companies used to face have been forgotten: apart from the obligation to use intermediaries to import their products onto the Chinese market (with recourse to legal proceedings limited to these intermediaries when the end client did not pay the entire sum due), there was the use of local distributors who were difficult to control, and even of frontmen for those foreign operators who tried to build embryonic distribution networks or open shops.

Today, China's marketing system is by and large similar to that of the developed countries, and the restrictions encountered by foreign companies

4. See Paolo Farah, "Five Years of China's WTO Membership, EU and US Perspectives on China's Compliance with Transparency Commitments and the Transitional Review Mechanism," Legal Issues of Economic Integration, Alphen aan den Rijn (Netherlands), Kluwer Law International, 2006, pp. 263-304

5. Article 9 of the PRC Foreign Trade Law adopted on 12 May 1994 determined objective conditions allowing those companies that could prove a certain volume of annual imports or exports to obtain a foreign trade operator's licence delivered by departments of the Ministry of Foreign Trade and Economic Cooperation (MOFTEC to give it its acronym at the time).

6. "Machimpex" for capital goods and COFCO for agri-food products were just two examples.

7. See the Measures for the Administration of Foreign Investment in the Commercial Sector that came into force on 1 June 2004, fixing the business scope authorised for foreign-invested commercial companies and providing for the possibility of setting up wholly foreign-owned enterprises in this sector from 11 December 2004 as stated in the WTO Accession Protocol. 
are more likely to be of a commercial rather than of a legal nature. Fierce competition reigns on the Chinese market, and certain forms of distribution that are current in Europe (for example, distribution chains specialising in DIY products or furnishings) have difficulty gaining a foothold in the face of traditional, more unsophisticated forms where price is of paramount importance.

\section{Harmonisation of regulations and government reforms}

Membership of the WTO corresponded to acceleration in the enormous task of legislation begun in the mid-1980s. The Chinese authorities amended or carried over almost 300 regulatory texts of national scale, ${ }^{(8)}$ without counting the immense amount of work carried out at the provincial and municipal levels. Most frequently however, these legislative and regulatory developments only concerned existing measures that contradicted the rules of the WTO or the commitments made by China in the Accession Protocol, with legislative work then gradually gathering momentum to construct, stage by stage, an increasingly comprehensive legal system.

In more general terms, the system applicable to foreign-invested enterprises became almost identical to that of purely domestic companies. ${ }^{(9)}$ Labour law applies to all, ${ }^{(10)}$ as does fiscal and contract law. Company law is almost always common to both, with the exception of texts applicable to Sino-foreign joint ventures that conserve certain specificities as compared to the company law (and notably, the requirement for unanimity in the Board and for the administrative approval of the most important questions, a guarantee of protection for minority interests). (11) Regulations that were previously vital for foreign investors, such as those applying to technology transfers, ${ }^{(12)}$ have disappeared or are no longer important.

The harmonisation of the Chinese legal framework was also accompanied in the first decade of the century by multi-form government reforms that significantly improved the situation of foreign companies. The principle of transparency led to the abandonment of internal regulations (neibu guiding), which up until then could be applied to foreign companies in a discretionary manner. Even in the absence of a national Official Journal, access to regulations is public and made easier by the many websites published by ministries and regulatory authorities. ${ }^{(13)}$ On-line administration is, in certain sectors, way ahead of Europe. Hotlines give access to competent civil servants who can be questioned on the application of such and such regulation, and these same government departments are generally available to deal with many questions during meetings. Civil servants are now younger, with the appointment of 40-year-olds to management posts in all local and provincial government departments. Better trained than their predecessors, they approach problems in a much more professional manner, and the arguments they develop are most often based on regulatory texts. This change of attitude is often expressed by answers such as, "You can do it because it's not forbidden by the regulations," replacing the "It's impossible because it is not mentioned in the regulations" of times gone by.

China's accession to the WTO has also strengthened the determination of the central government to pursue other reforms launched before 2001, such as reform of state-owned enterprises and financial institutions. Validated by the 15th Congress of the CCP in 1997, the policy of reforming state-owned enterprises consisted of "grasping the large (companies) and releasing the small" (zhuada fangxiao), resulting in the large-scale restructuring of tens of thousands of factories and concentrating the most strategic assets (energy, car manufacturing, steel and non-ferrous metals, aeronautics and space, chemicals, etc.), that is to say, almost 70 percent of the assets then held by the state, in several large companies supervised by the Stateowned Assets Supervision and Administration Commission (SASAC). Similarly, the streamlining of the financial system involved the confinement in default companies of non-performing loans that encumbered the balance sheets of Chinese banks. These fundamental reforms unquestionably contributed to the modernisation of the Chinese economy and to the maintenance of a high growth rate during the first decade of the century. Alongside this, the focusing of the administrative authorities on regulatory activities and the conversion of former administrative units into professional associations or independent service companies (for example for commodity inspection, engineering, or architecture) has also contributed to the creation of a more open market, even if historic links and personal relationships between former colleagues in the administration are still at the origin of many conflicts of interest.

\section{Commitments largely respected}

These administrative reforms allowed China to respect the letter of the commitments it had made in terms of market access for foreign companies. Set out in the Accession Protocol and its appendixes, these commitments have been copied into the successive versions of the Foreign Investment Catalogue, a tool in which the Ministry of Commerce enumerates a series of production processes for which foreign investment is forbidden, encouraged, or restricted. Activities that do not appear in the Catalogue are considered authorised by default. Foreign investment in categories of products or services identified as "restricted" is conditional upon the creation of joint ventures, sometimes with a majority Chinese shareholding, and/or a specific process of approval that takes the case to the national authorities. The latest version of the Catalogue, published on-line in April 2011 to gather comments and finally published on 24 December 2011, ${ }^{(14)}$ corresponds to the declared national policies by listing in the "encouraged" category many activities linked to the protection of the environment and "green" industries.

8. Wang Yong, Peking University School of International Studies, "Being in the WTO for Ten Years: China's Experience of Learning and Growing Confidence in Clobal Governance: Institutional Transformation and Interdependence," Indiana University Research Center for Chinese Politics \& Business, October 2011.

9. Chinese legislation drawn up around the beginning of the 1980s was mainly aimed at reassuring foreign investors, which explains why texts governing the activities of the latter often preceded Chinese common law in such or such a field. For example, a Foreign Economic Contracts Law dated 21 March 1985 remained applicable until the publication of the Contract Law of 15 March 1999. Similarly, the Sino-foreign Equity Joint Ventures Law dated 1 July 1979, the Sino-foreign Cooperative Joint Ventures Law dated 13 April 1988, and the Wholly Foreign-owned Enterprises Law dated 12 April 1986 preceded the Company Law dated 29 December 1993.

10. Since the PRC Labour Law of 5 July 1994

11. For example, Article 36 of the Implementing rules of the Sino-foreign Equity Joint Ventures Law states that "Board members must be unanimous in decisions concerning 1) amendments to the company articles of association 2) the suspension and dissolution of the company 3) increases or transfers of the registered capital and 4) a merger with another economic organisation."

12. See the PRC Administration of Technology Import Contracts Regulations of 24 May 1985 and its Implementing Rules of 30 December 1987, which provided a strict framework for the rights of the technology lessor, imposing a maximum duration for licences and making the effectiveness of each contract conditional upon its approval by the government. These regulations were replaced by a State Council regulation dated 18 December 2001 requiring most contracts to complete a simple registration formality and no longer requiring approval.

13. The websites of certain ministries also include a large range of laws and regulations translated into English.

14. Catalogue Guiding Foreign Investment in Industry (the "Catalogue"), published by the MOFCOM and the National Development and Reform Commission on 24 December 2011, applicable from 30 January 2012. 
The Chinese authorities have, in general, not ventured beyond the commitments to market opening set out in the Accession Protocol. This situation has caused a great deal of frustration amongst those who imagined that access to the WTO was the beginning of a process that would lead China to open up still further. ${ }^{(15)}$ Certain foreign operators are watching the rapid development of the Chinese market without being able to access it effectively, in particular in the service sector. Service activities are developing rapidly, and their reality no long necessarily corresponds to the nomenclature used during the accession negotiations 15 years ago. This is this case, for example, for new activities linked to information technologies.

Cases where China has opened up its market to a greater extent than planned ten years ago are rare. Nonetheless, a notable example is the case of travel agents providing services for Chinese tourists travelling outside China (outbound tourism). The WTO Accession Protocol envisaged the gradual opening up of the market to foreign travel agents, but only for foreign tourists visiting China (inbound tourism), or to provide services within China itself (domestic tourism). Tours abroad can only be sold by agencies holding a special licence delivered by the National Tourism Administration. In 2010 for the first time, the number of Chinese tourists travelling abroad $(57$ million) exceeded that of foreign tourists visiting China (55 million), (16) sharpening the appetite of big foreign tour operators, some of whom had begun to provide this type of service through complex, scarcely legal arrangements aimed at circumventing the regulations (use of a Chinese partner's licence or takeover of a Chinese company that holds such a licence, for example). In May 2011, the National Tourist Administration issued for the first time three outbound tourism licences to foreign operators as part of a "pilot" project of the sort that often heralds a more general relaxation of the rules. In this particular sector, one can imagine that several factors contributed to an unexpected opening up of the market: the rapid development of the market, which allowed everyone to find a place in it, the demand of Chinese clients for world travel under the same conditions as foreigners, new systems that allow tourists to reserve the tours of their choice via Internet, and the possibility of circumventing the ban that justified working with it rather than submitting to it.

\section{The difficulties of accessing the market}

Ten years after WTO membership, have foreign companies found compensations in the Chinese market for the increased competition from Chinese products on foreign markets? The answer to this question doubtless varies from sector to sector. Overall, foreign companies that develop a significant and profitable part of their activities in China, visible on their balance-sheet, either by exporting there or by manufacturing locally, belong to certain sectors: luxury goods and cosmetics, wine and certain alcohols, automobiles, ${ }^{(17)}$ Airbus and Boeing in the aeronautics sector, basic products, energy resources and raw materials that supply Chinese industry, electronic components mainly made in Japan, Taiwan, and Korea and then used in Chinese products, and certain manufacturing equipment that allows countries occupying a good position in this sector, such as Germany, to take full advantage of Chinese growth. On the other hand, there are many sectors in which foreign operators only have access to a fraction of the Chinese market: banking and insurance (around 2 percent of the market share), energy and transport (due to the presence of Chinese competitors for whom the big contracts are reserved), telephone operators (still the preserve of three Chinese operators anxious not to share a profitable market), the construc- tion sector (1 percent of the market share $\left.{ }^{(18)}\right)$, and many other professional service markets. Since China has overtaken Germany as the world's leading exporter, and competition from its products figures amongst the main causes of the growing de-industrialisation of certain Western countries, was its membership of the WTO nothing more than a front? And if China has by and large respected the letter of its access commitments to the WTO, why do foreign companies have so much difficulty finding their place on the Chinese market?

\section{The absence of a business freedom principle}

When attempting to analyse the obstacles faced by foreign companies in China, first and foremost it has to be said that the absence of a freedom of commerce and industry principle in Chinese regulations and administrative practices forms the background to very many difficulties. It is perhaps one of the most striking paradoxes that a country where the principles of a capitalist economy often operate in a rather abrupt manner is also a country that has preserved an administration that approves, controls, and regulates business activities.

China maintains a strict system of approval for foreign investments, whatever form they take. Foreign-owned companies can only be set up after approval by the Ministry of Commerce (MOFCOM), or more often, by its local or provincial representatives. This control concerns both the business scope of the projected company and its investment plans. If these affect regulated sectors or are covered by national policies (steel, aeronautics, car manufacturing, etc.), or exceed certain sums, the National Development and Reform Commission (NDRC, formerly the Planning Commission) must study and approve the project before it can be implemented. In the financial services sector, regulatory authorities have been set up ${ }^{(19)}$ to approve and supervise activities of banks, insurance companies, and other financial institutions financed by foreign capital. For simpler projects, such as the creation of a commercial subsidiary or a factory for the manufacture of non-regulated products, approval is at local level and is usually given fairly quickly. However, over the years, there has been an increase in the requirements of the authorities regarding the documents to be provided, their conformity to standards that differ from one municipality to another, and the formal requirements applicable to some of them.

Verification of the business scope by the authorities is fairly emblematic in this respect. Unlike Western countries, in which the creation of a company is a formality and the business scope of companies is simply a stylistic device that allows them to carry out all manner of activities, China applies a restrictive business scope principle when the company is founded (verification that a foreign capital company has been set up for activities authorised by the Catalogue) and also carries out an annual inspection that allows the

15. See, for example, the document submitted by the US-China Business Council following publication of the draft Catalogue Guiding Foreign Investment in Industry in 2011, which "respectfully suggests that the final version of the Catalogue follow the State Council's opinion on the importance of foreign investment and demonstrate substantial new openings in [the high technology and modern services sectors] and other sectors" (USCBC Recommendations for Revisions to the 2011 Catalogue, p. 1).

16. European Business in China Position Paper 2011/2012, Travel Working Group, p. 257.

17. China has become the world's leading market for private vehicles, with 14 million sold in 2010, 800,000 of which were imported, in particular high-end German sedans. See European Business in China Position Paper 2011/2012, Automotive Working Group, p. 111.

18. European Business in China Position Paper 2011/2012, Construction Working Group, p. 215.

19. China Banking Regulatory Commission (CBRC), China Insurance Regulatory Commission (CIRC), China Securities Regulatory Commission (CSRC). 
Administration for Industry and Commerce (Gongchangju) to check that the company is only operating for the purposes laid down in its business scope. Business scope determines not only the activities of companies, but also their fiscal status. So a service company, whose business is subject to the Business tax, does not have access to the VAT system ${ }^{(20)}$ and is therefore prevented from buying products for re-sale. Companies that engage in activities falling outside their business scope run the risk of incurring sanctions ranging from a simple fine to the withdrawal of their business licence, in a context where denunciations to the department concerned are not unknown.

In addition to this verification of the business scope, a system of delivery for permits and licences exists in many domains, allowing the authorities to restrict the geographical area (for example, licences delivered province by province for insurance activities) or to control the number of operators in certain sectors (advertising, market surveys, and teaching, to name but a few). The certification of products does not escape discretionary or discriminatory practices.

The foreign exchange control is another obstacle foreign or foreign-invested companies must face. WTO rules do not require total currency convertibility of a member country, but simply the free convertibility of sums corresponding to current operations (purchases of goods and services, payment of salaries and dividends in foreign currency, etc.). Within the space of ten years, the purpose of foreign exchange controls has changed. Originally designed to prevent the escape of foreign currency, they are now mainly used to protect China from incoming flows of foreign currency because of the constraints these movements place on Chinese currency. In practice, the administrative difficulties the exchange control mechanisms present for Chinese subsidiaries of foreign companies are legion: the impossibility of cash advances to subsidiaries by the parent company (these must take the form of shareholder loans, documented and registered with the State Administration of Foreign Exchange), problems of financing development operations in China other than by increases in capital (subject to approval), invoices from foreign service providers to Chinese entities paid late or considered "too complex" by a Chinese client on the pretext of the exchange control, or the practical impossibility of transferring foreign capital that has nonetheless been approved when the local exchange control bureau has exhausted its annual quota of incoming currency and its civil servants risk being deprived of their bonuses if the quota is exceeded. Guarantees in foreign currency are subject to the same preliminary registration system by the foreign exchange authorities as capital flows. They, too, cause many problems, from the difficulty of a parent company to extend guarantees to the activities or borrowing of its Chinese subsidiary, to the difficulty of setting up a seller's warranty in favour of foreign purchasers of companies, and including the difficulty for a foreign company or bank to take out a mortgage or any other kind of security in China.

\section{Tools of resistance to the opening up of the market}

Given that a "WTO spirit" that would lead the authorities to open up access to the market as a whole has not taken root in China, what tools have they used to resist the demands and initiatives of foreign companies? Even though these tools often take many forms, they all possess a certain subtlety that generally prevents identification of a flagrant violation of the commitments taken at the time of accession or in relation to the rules of the WTO.
A first tool is the application of the principle of national treatment. A complexity applicable to Chinese companies is equally applicable to foreignowned companies, even if it prevents the latter from effectively accessing the market. Construction is one of the sectors in which the application of national treatment has led, in practice, to the exclusion of very many foreign operators. The Ministry of Construction has set up checks on the aptitude of entities authorised to work on construction projects by delivering $A, B$, or $C$ qualification licences depending on the technical difficulty of the project, with sub-categories applicable to certain kinds of work. The system applies to construction companies themselves as well as to firms specialising in architecture, engineering, technical controls, and project management. The WTO Accession Protocol made provision for a degree of opening up of the construction sector to foreign-owned companies, but the latter find that most of the time they are barred from taking part in the projects that interest them, which are generally those requiring a Grade $\mathrm{A}$ licence. The requirements for obtaining - and keeping - the licence include, for example, a minimum number of qualified engineers and technicians, a minimum level of registered capital, and a portfolio of similar completed projects. ${ }^{(21)}$ These criteria apply to all Chinese or foreign-owned companies, but just as it is easy for a Chinese architecture or engineering practice to justify an existing team and project portfolio, it is difficult for a foreign firm to justify experience that would qualify them for the job when only work done in China is accepted by the authorities in charge of examining the application for qualification. Lack of qualifying experience in China means no licence; no licence means no chance to build up a portfolio of qualifying experience and therefore no real access to the market.

Exclusion from the market for lack of a local partner is another resistance tool. An illustration of this can be found in the telecommunications sector, in which American and European negotiators fought hard for their operators to have a chance to access the market within the framework of joint ventures, in a context where the projects of foreign operators within the framework of CCF (China-China-Foreign) projects had just been dismantled by order of the national authorities. ${ }^{(22)}$ These companies could only be set up with Chinese partners in possession of a telephone operator's licence, and since the three companies already in the sector were keen to preserve their monopoly, it has never been possible to set up a Sino-foreign joint venture to offer either fixed or mobile telephone services, and no foreign operator can hope to do business in this sector in China, whilst value-added telecommunications services, which are on the whole defined and supervised by the Ministry of Information Industry, are also by and large closed. (23)

Differentiated application of the regulations constitutes a third tool identified as a major obstacle by European companies questioned by the European Chamber of Commerce. (24) Foreign-owned companies have become

20. At least until the introduction of VAT on service activities, the implementation of which has already begun in Shanghai for services with high added-value, and which is expected to be extended.

21. European Business in China Position Paper 2011/2012, Construction Working Group, pp. 216-217.

22. CCF (China-China-Foreign) projects had been established by foreign operators in collaboration with Chinese operators in the shape of wholly foreign-owned service companies that financed the investments of the Chinese operators and invoiced technical services that enabled them, under the terms of a contract, to share risks and income. These projects, approved by the Ministry of Commerce, were declared "irregular" by the Ministry of Information Industry in October 1988.

23. European Business in China Position Paper 2011/2012, Information and Technology Working Group, p. 225.

24. "The discretionary enforcement of broadly drafted laws and regulations" is a major regulatory obstacle for 46 percent of the European companies questioned in the annual survey on the business confidence of European companies present in China, carried out by the European Chamber of Commerce in China in association with Roland Berger in 2011. 
accustomed, over many long years, to paying social contributions for employees whilst their Chinese competitors are often able, thanks to specific agreements with the local authorities, to pay much lower flat-rate sums. Since the promulgation of the law on labour contracts ${ }^{(25)}$ and other texts pertaining to social security cover, harmonisation is underway, with contribution rates applicable to all. Nonetheless, after the start of the financial crisis in 2008, many purely domestic companies suffering a slow-down in their exports were consequently exempted from national laws that continued to apply to foreign-owned companies. Foreign-owned factories are liable to find themselves paying fines for the non-respect of environmental regulations and receiving orders to bring their establishments up to standard, whilst neighbouring competitors emitting far greater and more dangerous polluting substances escape all sanctions. Foreign insurance firms complain that restrictions imposed on the distribution of insurance products by the banking networks (which, since they generate large commissions, can only be implemented through agreements with banks at the central level and not with their local branches) are applied differently to companies depending on whether or not they are financed by foreign capital, and that Chinese firms continue commissioning practices with local branches of banks although the regulatory authority has already penalised foreignowned firms for these same practices.

These discriminatory practices are similar to those that make it difficult to access the public procurement markets that are a top priority for the European Union and the United States in their current discussions with China. (26) Indeed, it can be seen that foreign companies or foreign-owned companies can find themselves excluded from certain government contracts or contracts launched by state-owned companies, even after investing in local production capacity and adapting their products to Chinese norms. Companies of European origin have, for example, complained of exclusion from the gigantic wind-farm projects envisaged in China, particularly offshore. (27)

In the offshore wind-farm sector, the reasons given by the Chinese authorities for insisting that foreign bidders are joint ventures with a majority Chinese shareholding relate to the imperatives of national security. ${ }^{(28)}$ The concept of national security is a tool increasingly used to restrict access to the market, preventing foreign companies from buying Chinese companies in several business sectors (naturally including companies in the defence sector as well as companies in certain key sectors of agriculture, energy and resources, transport systems, and some manufacturing equipment sectors). ${ }^{(29)}$ It can also be seen in China's standardisation policy, as well as in many other areas, for example in the policy applicable to the encrypting of information systems that covers both military and commercial uses and obliges foreign manufacturers to reveal highly confidential information such as that relating to the source codes of the encrypting system. ${ }^{(30)}$

China therefore makes full use of non-tariff barriers to protect its market and favour its companies. Other member-states of the WTO do not hesitate to use similar means to protect their markets or to evoke the imperatives of national security to prevent foreign companies from acquiring certain jewels in their industrial crown. The situation is, however, specific in China because of the importance of the commercial stakes (local market prospects nourish special expectations on the part of foreign companies) and the competition Western companies increasingly face in their own markets and in third markets from new Chinese challengers. They have the impression, often well-founded, that there is no reciprocity in the access conditions to the Chinese market and to the market in their country of origin. ${ }^{(31)}$
The principle of national treatment is at the very heart of WTO principles and obliges a member-state to treat all companies, whether wholly Chinese or with foreign capital, on equal terms. The nationality of a company has, moreover, become a subject of debate in Europe, refuted by some who think of themselves as "international." For its part, China remains interested in the nationality of its companies and has difficulty treating all companies in the same way. If Prime Minister Wen Jiabao declared on 13 September 2010 that he "would like to reiterate that all enterprises registered in China in accordance with law are Chinese companies," (32) it was because things are in general seen differently both by most foreign investors and by many government departments and Chinese civil servants.

In point of fact, China's policy is qualified by some as "Gaullist" in that its aim is to acquire autonomy in most industrial sectors and launch its national champions into the conquest of world markets. To this end, China does not hesitate to make technology transfers a condition of access to its own markets and to reserve subsidies and preferential terms of access to bank finance for national companies. Anxious to support the rise of its industry and to encourage Research and Development, it has decreed a multiform policy of "indigenous innovation." Although the Chinese government has renounced restricting access to public markets to products on the list of "indigenous innovations" it has drawn up, the practices of the authorities, in particular local authorities, often seem different to foreign operators. Without being naive about the measures many other countries also take to favour their own companies, the relationship between the principle of national treatment and the legitimacy of China's economic development policy would nonetheless seem to raise many questions.

\section{Possible improvements or structural obstacles?}

In the light of the above, is there any room for improvement to ensure that the principles of transparency, national treatment, and judicial review that structure the WTO's approach are better respected? In other words, must we believe that the malfunctioning of the market, the lack of respect for intellectual property, corruption, and the absence of a reliable court system will disappear as China's economic development and modernisation program progress, or do we find ourselves in a specific situation leading us

25. PRC Labour Contract Law of 29 June 2007, which came into force on 1 January 2008.

26. Negotiations under way on China's adherence to the WTO's Public Markets Agreement (WTO GPA).

27. European Business in China Position Paper 2011/2012, Renewable Energy Working Group, p. 196.

28. Idem, p. 196.

29. Provisions on the Acquisition of Domestic Companies by Foreign Investors (2006) mentions possible checks on the grounds of national security, formalised in a Circular issued by the State Council on 5 March 2011 (Circular of the General Office of the State Council on Establishing a Security Review System for Mergers and Acquisitions of Domestic Enterprises by Foreign Investors). The practice of merger control, begun in 2003 and implemented in practice with the coming into force of the Anti-monopoly Law of 1 August 2008, has not so far dissipated suspicions that it is being used as a form of economic protectionism.

30. "Information security regulation in China is marked by heavy restrictions towards foreign market access on the grounds of appeals to national security, as well as a lack of clarity and transparency," European Business in China Position Paper 2011/2012, Information Security Industry Working Group, p. 229.

31. "Compared to its major trading partners, China is by far the most restricted in foreign investment, both in restricting and in requiring approval of individual investments rather than simple registration or notification. Since China is now growing rapidly as a foreign direct investor, the lack of reciprocity will certainly lead to friction." Christian Murck, President of the American Chamber of Commerce in China (AmCham China), on the Tenth Anniversary of China's WTO Accession, Caixin, 11 January 2012.

32. "China's Wen Promises Fair Play for Foreign Investors," 13 September 2010, Reuters. 
to believe that as a result of political and cultural obstacles, China will remain a special case in international trade relations?

\section{The case of intellectual property}

Intellectual property has been a focus of attention for China's main partners for many years now, since China is seen as the number one country for counterfeit goods. Accession to the WTO has closed the gap that existed between Chinese legislation and the principles figuring in the rules of the WTO. ${ }^{(33)}$ Well-known marks are now recognised, and the registration of three-dimensional trademarks has been authorised. But have things really changed? We can credit the Chinese authorities with conducting more anti-counterfeiting campaigns than before, of attempting to develop a sense of product quality amongst consumers, and of understanding the economic usefulness of brand protection. However, commercial parasitism remains endemic alongside counterfeit goods that continue to affect Chinese and foreign products alike. Without carrying out a technical analysis of these questions, which is beyond the scope of this article, we can highlight a deviation from the meaning of intellectual property such as it figures in the treaty regime set up at the end of the nineteenth century and to which China adhered. Admittedly, the system of patent protection has been called into question at world level, in particular for products such as pharmaceutical drugs from which the most underprivileged populations are excluded. But it is in China that the most widespread criticisms are developing concerning the market power obtained by international companies through their intellectual property rights. Moreover, the very purpose of a patent as temporary protection for a discovery or of trademarks as protection of the prestige of a product would seem to be challenged by the practices of Chinese companies, sometimes with the complicity of the trademark and patents offices. Foreign companies that respect the principle of patent claims limited to patentable inventions (notably with regard to the prerequisite of novelty) are put at a disadvantage in comparison with Chinese companies who manage to register - and maintain - a far wider field of claims before attacking foreign companies on the grounds of counterfeiting. Verification of the novelty contained in the patent application, which Chinese examiners have been obliged to carry out since 2009, does not prevent certain Chinese companies from registering patents for inventions that have fallen into the public domain abroad. The tax advantages applicable to technology-advanced enterprises, which must be justified by at least two registered patents, has led to a trade in artificial patents that partly puts into perspective the sharp increase in the number of patents registered in China in recent years. Well-known marks, which are the object of recognition by the government or by the tribunals, have become a marketing tool used by hitherto largely unknown Chinese brands, to the point where the Chinese authorities have sought to limit the possibilities for recognition of well-known marks by the tribunals.

So are these deviations from the spirit of the international intellectual property protection system a sign of the immaturity of the Chinese market, which will progressively disappear, or the sign of a conception of intellectual property that is specific to China and therefore here to stay? There are many arguments to support either thesis.

\section{Playing with the rules}

Problems of applying the regulations regarding intellectual property are in line with other observations on legal practices in China. These often give the impression that the rule of law is less the framework for fair commercial transactions than a tool with which certain parties can play better than others. In most countries, there are numerous, sometimes over-complex rules, but principles lie behind the law and allow the judge to signal the end of the game when one party tries to play too much on the letter of the law in order to circumvent its spirit. In China, the regulations are similarly extensive, sometimes even more technical and complex in order to deal with the problems arising from rapid economic development, and are sometimes purposely vague in order to leave the administrative authorities sufficient room to manoeuvre. Frequently however, the approach adopted by Chinese companies, the departments concerned, or the tribunals demonstrates a purely functional idea of the ruling, detached from the principals that should animate it.

The Danone/Wahaha case is fairly representative in this respect. Without knowing all the ins and outs of the situation, ${ }^{(34)}$ it is clear that Danone had acquired 51 percent of the capital of Wahaha in the mid-1990s, and that following a disagreement between Wahaha's founder, Zong Qinghou, who wanted to develop use of the brand name for other products outside the joint venture company, and Danone, who hoped to prevent this, several proceedings were launched both inside and outside China. The case, which led to widespread debate on the Internet, could not be settled under the aegis of the Chinese and French public authorities, leading Danone to sell its shares after ending the arbitration procedure it had launched. In fact, it transpired that it was not possible for Danone to exercise its majority shareholder rights, that Chinese public opinion, without taking into account the initial agreement, was squarely behind a Chinese shareholder facing up to a foreign multinational, and that the principle of the binding nature of contracts gave way in the face of the idea that a foreign shareholder who merely profited from the growth of the business of the company in which he had invested was not legitimate in forbidding the Chinese manager to apply the policy of his choice.

In this case as in others, it can be seen that the very idea of a contract does not, in practice, mean the same thing in China as in Europe. It is not the legal provisions that are in question (the Chinese law of contracts is close to that of continental Europe), but their application. The contract is not, as one might expect, so much a document that sets down the expectations of the parties, as it is a framework for their relationship that must evolve as circumstances change. Hence the constant renegotiations and a certain measure of "good faith" on the part of the Chinese side in their refusal to apply such and such clause of a contract. ${ }^{(35)}$

Chinese judges are increasingly professional, but obliged to work in a way that does not guarantee their independence. The tribunals can sometimes

33. Trade-Related Aspects of Intellectual Property Rights (TRIPs).

34. The parties ended their conflict by a transactional protocol that almost certainly contained a confidentiality clause preventing them from testifying in what must have nonetheless been a textbook case of the state of relations between Chinese and foreign partners in a joint venture. We know that the initial acquisition contract mentioned a transfer of the trademark to the joint venture that did not take place for reasons relating to the Chinese administrative authorities and that in the meantime, a licence contract ordered the conditions under which the trademark could be used by the joint venture. The clauses pertaining to the settlement of disputes, which differ from contract to contract, led to the opening of international arbitration proceedings in Stockholm on the basis of the joint venture contract and internal arbitration proceedings in Hangzhou on the basis of the trademark licence.

35. To take one example amongst many, a European company that had signed a joint venture contract with a Chinese partner 15 years previously that included a clause forbidding the Chinese partner to enter into competition with the joint venture, took the said partner to task over its avowed disrespect of this clause, and found itself offered the possibility of simply erasing the clause so that the contract would be in conformity with this new reality. 
become, through various forms of pressure, the tool of local protectionism, reducing the effectiveness of the judicial review stated in the rules of the WTO. Foreign or foreign-owned companies are loath to ask a Chinese judge to settle commercial differences and prefer compromise and discussion to the risk of prejudicial or biased legal proceedings. They almost never act against the government, even when it does not respect its rules. They often agree to pay unjustified fines and to submit to abusive injunctions rather than contest administrative decisions in the courts, fearing to give themselves a bad image or even to suffer retaliatory measures if they embark on this path. These observations, which are not isolated examples, represent the situation of the rule of law in China ten years after its accession to the WTO, with progress in a context that lacks transparency, the rule of law often being used solely to protect local and national interests. It was doubtless illusory to think that China's access to the WTO was going to bring about sudden change in the Chinese administrative and legal system. Questions remain to be answered, notably on the possibilities for improving the business framework in China with regard to the fair application of rules, administrative transparency, national treatment, and effective judicial review, which appear in the rules of the WTO. Some observers recommend patience to allow China to modernise its traditions as it progressively integrates into world trade, confident that the country's rapid economic development will one day end in a harmonisation of rules and practices. Others, however, are more circumspect, asking themselves if China has not exhausted all possibility of improvement under its current system, and if future improvements are possible so long as the regime has not found any way to achieve real political reform. ${ }^{(36)}$ It is interesting to note that these differences in analysis between the "optimists" and the "pessimists" can be found both in foreign companies in China and amongst the Chinese themselves.
To look at the modernisation of China from the legal point of view is necessarily to be impressed by the efforts made to build, almost from scratch, a relatively comprehensive legal system. Yet experience of the practice of law in China also brings its share of disappointments and frustration in the face of the often inoperable nature of the rule of law.

Ten years ago, China demanded its accession to the WTO as part of its status as a great power in the making. Its argument of a WTO incomplete without the presence of one of the great players of world trade was accepted by the member-states, who nonetheless sought guarantees and compensations in the form of access to the market and reductions in customs duties. In ten years, the international context has changed remarkably. More than any other country, China has benefited from the globalisation of trade, but must face an increase in labour costs and the reorientation of its economic system towards growth that is more respectful of natural resources and directed more towards its domestic market. The model represented by Western countries was damaged by the financial crisis of 2008, whilst the managerial classes face increasingly strong pressure in favour of de-globalisation and a return to forms of protectionism. Today's view is that the harmonisation of the rules of world trade cannot be achieved simply by transplanting a "Western" system, and the need for international regulation remains more urgent than ever. In this context, we would like the Chinese players, who are also confronted with difficulties in accessing the markets of Western countries and with new problems of managing subsidiaries abroad, to be able to suggest possibilities for development and the harmonisation of practices. These can only be credible, however, if they are founded on greater reciprocity.

\section{Translated by Elizabeth Guill}

